\title{
PROSPEK DAN KONTRIBUSI KOMODITAS PADI (Oriza sativa) TERHADAP PDRB SEKTOR PERTANIAN DI PROVINSI KALIMANTAN UTARA, INDONESIA
}

\author{
(PROSPECTS AND CONTRIBUTION OF RICE (Oryza sativa) \\ COMMODITIES TO GRDP OF THE AGRICULTURAL SECTOR IN \\ NORTH KALIMANTAN PROVINCE, INDONESIA)
}

\author{
Nurlela Machmuddin, Khaerunnisa, Emilianus Liko \\ Fakultas Pertanian, Universitas Borneo Tarakan \\ *nurlela@borneo.ac.id
}

\begin{abstract}
Abstrak: Kalimantan Utara sebagai salah satu provinsi baru dan berada langsung di wilayah perbatasan dituntut untuk dapat mengembangkan sumberdaya alam yang dimiliki secara optimal utamanya di sektor pertanian dalam hal pemenuhan pangan beras yang semakin meningkat dan diharapkan dapat menjadi wilayah penyangga pangan untuk ibu kota baru nantinya. Besar kecilnya produksi padi akan berpengaruh terhadap ketersediaan padi atau beras dan secara tidak langsung juga berdampak pada kontribusinya terhadap Produk Domestik Regional Bruto (PDRB). Penelitian ini bertujuan untuk mengetahui prospek perkembangan komoditas padi di Provisi Kalimantan Utara ditinjau dari produksi, luas panen dan produktivitasnya; dan menganalisis kontribusi subsektor tanaman pangan terhadap PDRB bidang usaha pertanian, peternakan, perburuan dan jasa di Provisi Kalimantan Utara. Metode analisis yang digunakan adalah deskriptif kualitatif dengan pendekatan review literature dan penelusuran data sekunder berupa jenis data time series periode tahun 2013-2018. Analisis trend linier dan rumus proporsi digunakan Untuk mengetahui prospek dan kontribusi. Hasil analisis trend menunjukkan bahwa produksi padi cenderung mengalami trend penurunan yang diakibatkan olah trend penurunan luas panen, sedangkan produktivitasnya cenderung mengalami pelandaian (levelling off). Hal ini menunjukkan bahwa komoditas padi belum mampu dijadikan sebagai sektor unggulan di provinsi Kalimantan Utara. 2) kontribusi subsektor tanaman pangan terhadap PDRB bidang usaha pertanian, peternakan, perbutuan dan jasa di Provisi Kalimantan Utara sebesar 11.94 persen di bawah rata-rata kontribusi di sektor tersebut (15.09 persen) sehingga dapat disimpulkan bahwa Provinsi Kalimantan Utara belum bisa mengandalkan sub sektor tanaman pangan untuk peningkatan PDRB.
\end{abstract}

Kata kunci: Padi, PDRB, Sektor Pertanian 
Abstract: North Kalimantan, as a new province and is directly located in the border area, is required to be able to develop its natural resources optimally, especially in the agricultural sector, in terms of the increasing fulfillment of rice food and it is hoped that it can become a food buffer area for the new capital city later. The size of rice production will affect the availability of rice or rice and indirectly also have an impact on its contribution to the Gross Regional Domestic Product (GRDP). This study aims to determine the prospects for the development of rice commodities in the province of North Kalimantan in terms of production, harvested area and productivity; and analyzing the contribution of the food crop subsector to the GRDP in the agricultural, livestock, hunting and service sectors in the North Kalimantan Province. The analytical method used is descriptive qualitative with a literature review approach and secondary data tracing in the form of time series data for the period 2013-2018. Linear trend analysis and proportion formula are used to determine prospects and contributions. The results of the trend analysis show that rice production tends to experience a downward trend due to a decreasing trend in harvested area, while the productivity tends to experience leveling off. This shows that the rice commodity has not been able to become a leading sector in North Kalimantan province. 2) the contribution of the food crop sub-sector to the GRDP of the agricultural, livestock, plants and services business in the North Kalimantan Provision of 11.94 percent below the average contribution in that sector (15.09 percent) so it can be concluded that North Kalimantan Province cannot rely on the plant sub-sector. food to increase GRDP.

Keywords: Rice, GRDP, Agricultural Sector

\section{PENDAHULUAN}

Pangan merupakan suatu kebutuhan dasar utama bagi manusia untuk dapat mempertahankan hidup, oleh karena itu kecukupan pangan bagi setiap orang pada setiap waktu merupakan hak asazi yang harus dipenuhi (Ariani, 2004).

Sebagai kebutuhan dasar dan hakazazi manusia, pangan mempunyai peran yang sangat penting bagi kehidupan suatu bangsa dan negara. Ketersediaan pangan yang lebih kecil dibandingkan dengan kebutuhannya dapat menciptakan ketidak stabilan ekonomi suatu negara. Berdasar kenyataan tersebut masalah pemenuhan kebutuhan pangan bagi seluruh penduduk setiap saat di suatu wilayah menjadi sasaran utama kebijakan pangan bagi pemerintahan suatu negara.

Tujuan dari pembangunan ketahanan pangan adalah 
terwujudnya kemandirian pangan yang cukup dan berkelanjutan bagi seluruh penduduk melalui produksi dalam negeri.

Ketersediaan pangan disuatu daerah dan pada saat waktu tertentu dapat dipenuhi dari tiga sumber, yaitu produksi dalam negri, impor pangan, dan cadangan pangan. Ketersediaan pangan untuk memenuhi kebutuhan pangan diupayakan melalui produksi dalam negri termasuk cadangan pangan. Impor pangan merupakan pilihan terakhir jika terjadi kelangkaan produksi pangan (Widianingsih, Suryantini, \& Irham, 2016).

Tanaman pangan merupakan salah satu sub sektor pendukung sector pertanian yang terdiri dari beberapa komoditi yaitu padi, jagung, kedelai, kacang tanah, ubi kayu dan ubi jalar yang tidak sedikit sumbangannya terhadap perekonomian daerah.

Salah satu Nawa Cita Presiden Joko Widodo adalah "Mewujudkan kemandirian ekonomi daerah dengan menggerakkan sektor-sektor strategis ekonomi domestik". Kemandirian ekonomi salah satunya dalah terkait kemandirian dalam penyediaan pangan, terutama padi atau beras yang merupakan bahan makanan pokok bagi sebagian besar rakyat Indonesia (Budiyanto 2018)

\section{TINJAUAN PUSTAKA}

\section{Komoditas Padi}

Padi merupakan bahan makanan yang menghasilkan beras, berfungsi sebagai makanan pokok bagi sebagian besar penduduk Indonesia. Beras adalah bahan makanan yang merupakan sumber pemberi energi. Beras mengandung nilai gizi yang tinggi, selain itu gizi yang dikandung oleh beras adalah sangat mudah dicerna oleh tubuh. Susunan gizi yang membuktikan keunggulan beras sebagai pemberi energi yang lebih tinggi dibandingkan dengan bahan makanan lainnya (Hotimah $\mathrm{H}$ S, 2014).

Beras merupakan makanan pokok sebagian besar bangsa Indonesia. Permintaan akan beras meningkat dari waktu ke waktu dengan makin bertambahnya jumlah penduduk. Pemenuhan kebutuhan pangan, produksi beras harus selalu ditingkatkan. (Purwaningsid, 2008); (Budiyanto 2018); (Rahayu, 2019).

\section{Produk Domestik Regional Bruto (PDRB)}

Indikator yang paling lazim digunakan untuk mengukur dan membandingkan skala perekonomian suatu negara adalah PDRB, yaitu nilai seluruh barang dan jasa yang dihasilkan suatu perekonomian dan dijual di pasar selama periode tertentu, biasanya satu tahun, ditambah hasil produksi barangbarang dan jasa-jasa diri modal asing yang ikut bekerja di daerah tersebut (Agustarita, V. dan Sudirman, W : 2015). 
Kontribusi adalah sumbangan atau peranan yang diberikan oleh masing-masing sektor terhadap Produk Domestik Bruto (PDRB). PDRB yang dikaitkan dengan perumusan kebijakan pemerintah dibedakan menjadi 2 jenis, yaitu menurut Jringan M (2007) :

1) PDRB atas harga dasar, adalah jumlah produksi barang dan jasa yang dinilai atas harga yang ditetapkan pada tahun tertentu (atas dasar harga tetap)

2) PDB atas harga yang berlaku, adalah produksi barang dan jasa yang dinilai atas harga yang berlaku pada tahun yang bersangkutan (atas dasar harga berlaku)

Perhitungan besarnya produk domestik regional bruto seluruh lapangan usaha yang dibagi menjadi 9 sektor usaha/ekonomi, yaitu: pertanian dalam arti luas, pertambangan dan penggalian, industri pengolahan, listrik, gas dan air bersih, bangunan, perdagangan, hotel dan restoran, pengangkutan dan komunikasi, keuangan dan persewaan bangunan dan jasa perusahaan dan sektor jasa-jasa (BPS,2020).

\section{Ketahanan Pangan}

Dapat dipahami bahwa keberhasilan pembangunan di sektor pertanian di suatu negara harus tercerminkan oleh kemampuan negara tersebut dalam swasembada pangan. Pangan merupakan istilah yang teramat penting bagi pertanian karena secara hierarkhi pangan merupakan salah satu kebutuhan yang sangat mendasar dalam pemenuhan aspirasi humanistic. Ketahanan pangan dapat didefinisikan sebagai suatu keadaan dimana semua rumah tangga baik secara fisik maupun ekonomi mampu mencukupi kabutuhan pangan seluruh anggota keluarganya. Hal ini sesuai dengan yang dikemukakan oleh Bidiyanto (2018) bahwa pangan merupakan kebutuhan dasar yang pemenuhannya tidak dapat ditundatunda, sehingga usaha untuk pemenuhan pangan merupakan prioritas utama bagi semua negara.

FAO menyatakan bahwa Ketahanan Pangan adalah "situasi di mana semua orang dalam segala waktu memiliki kecukupan jumlah atas pangan yang aman (safe) dan bergizi demi kehidupan yang sehat dan aktif. World Bank juga mengidentifikasi bahwa Ketahanan pangan adalah: "akses oleh semua orang pada segala waktu atas pangan yang cukup untuk kehidupan yang sehat dan aktif. Sedikitnya ada empat element ketahanan pangan berkelanjutan (sustainable food security) di level keluarga yang diusulkan oleh Maxwell (1996), yakni: pertama, kecukupan pangan yang didefinisikan sebagai jumlah kalori yang dibutuhkan untuk kehidupan yang aktif dan sehat. 
Kedua, akses atas pangan, yang didefinisikan sebagai hak (entitlements) untuk berproduksi, membeli atau menukarkan (exchange) pangan ataupun menerima sebagai pemberian (transfer). Ketiga ketahanan yang didefinisikan sebagai keseimbangan antara kerentanan, resiko dan jaminan pengaman sosial. Keempat, fungsi waktu manakala ketahanan pangan dapat bersifat kronis transisi dan/atau siklus (Hariani R, dkk 2019).

Konsep ketahanan pangan (food security) sedikit lebih luas dibanding dengan konsep swasembada pangan dan bahkan kemandirian pangan. Beberapa ahli sepakat bahwa ketahanan pangan minimal mengandung dua unsur pokok, yaitu "ketersediaan pangan" dan "aksesibilitas masyarakat" secara individu terhadap bahan pangan. Jika hanya salah satu unsur tersebut terpenuhi maka suatu negara belum dapat dikatakan mempunyai ketahanan yang baik. Walaupun pangan tersedia cukup di tingkat nasional dan regional tetapi jika akses individu untuk memenuhi pangannya tidak merata, maka ketahanan pangan masih dikatakan rapuh. Ketersediaan dan kecukupan pangan juga mencakup kuantitas dan kualitas bahan pangan agar setiap individu dapat terpenuhi standar kebutuhan kalori dan protein setiap waktu untuk menjalankan aktivitas ekonomi dan kehidupan sehari-hari
(Purwaningsih Y, 2008) (Hotimah S H, 2014)

\section{METODOLOGI PENELITIAN}

Tahapan metode penelitian yaitu observasi dan pengumpulan data. Metode analisis yang digunakan adalah deskriptif kualitatif dengan pendekatan review literature dan penelisuran data sekunder berupa jenis data time series periode tahun 2013-2018 yang diperoleh dari BPS Provinsi Kalimantan Utara dan Dinas Pertanian dan Ketahanan Pangan Provinsi Kalimantan Utara.

Untuk mengetahui prospek komoditi padi terhadap subsektor tanaman pangan dan terhadap PDRB sector pertanian di Provinsi Kalimantan Utara digunakan analisa trend linier.

Analisis trend digunakan untuk mengetahui perubahan nilai suatu variabel dari waktu ke waktu dalam hal ini adalah perubahan produksi, luas panen, dan produktivitas padi di Provinsi Kalimantan Utara. Analisis trend linier yang digunakan adalah sebagai berikut :

$$
\mathbf{Y}=\mathbf{a}+\mathbf{b x} \ldots \ldots \ldots \ldots \ldots \ldots . .(\text { pers } 1)
$$

dimana :

$\mathrm{Y}=$ nilai variabel yang ditentukan (produksi, luas panen, dan produktivitas padi)

$\mathrm{a}=$ nilai $\mathrm{Y}$ apabila $\mathrm{X}$ sama dengan nol 
$\mathrm{b}=$ kemiringan (slope) garis trend atau perubahan nilai $\mathrm{Y}$ dari waktu ke waktu

$\mathrm{x}=$ periode waktu yang digunakan Sedangkan untuk mencari nilai a dan $\mathrm{b}$ adalah sebagai berikut :

$$
\begin{aligned}
\mathbf{a} & =\frac{\sum Y}{n} \ldots \ldots \ldots \ldots . .(\text { pers } 2) \\
\mathbf{b} & =\frac{\sum X Y}{\sum X^{2}} \ldots \ldots \ldots \ldots . .(\text { pers } 3)
\end{aligned}
$$

dimana :

$\mathrm{n}=$ banyaknya tahun yang

digunakan

$\mathrm{x}=$ kode waktu masing-masing tahun

$\mathrm{y}=$ nilai variabel deret berkala

Untuk mengetahui kontribusi kontribusi subsektor tanaman pangan terhadap PDRB total sektor usaha pertanian, peternakan, perbutuan dan jasa di Provisi Kalimantan Utara. tahun 2014-2018 digunakan rumus proporsi sebagai berikut : (Tirani, Pranoto, \& Moelyo, 2018)

$$
\mathrm{Z}=\frac{X_{i}}{Y_{i}} \times 100 \% \ldots \ldots . . . . . .(\text { pers } 4)
$$

dimana :

$\mathrm{Z}=$ Kontribusi sub sektor tanaman pangan terhadap PDRB usaha pertanian, peternakan, perbutuan dan jasa

$\mathrm{Xi}=$ PDRB komoditas tanaman pangan ( $\mathrm{Rp}$ )

$\mathrm{Yi}=\mathrm{PDRB}$ total usaha pertanian, peternakan, perbutuan dan jasa (Rp)

Kriteria pengambilan

keputusan :

- Jika Z > dari rata-rata PDRB usaha pertanian, peternakan, perbutuan dan jasa maka kontribusi komunitas tanaman pangan terhadap PDRB sektor usaha pertanian, peternakan, perbutuan dan jasa tinggi

- Jika $Z \leq$ dari rata-rata PDRB usaha pertanian, peternakan, perbutuan dan jasa maka kontribusi komunitas tanaman pangan terhadap PDRB sektor usaha pertanian, peternakan, perbutuan dan jasa rendah.

\section{HASIL DAN PEMBAHASAN}

Provinsi Kalimantan Utara sebelumnya merupakan bagian dari provinsi Kalimantan Timur. Kemudian melalui Undang-Undang Nomor 20 tahun 2012, Kalimantan Timur bagian utara dimekarkan menjadi sebuah provinsi yang otonom.

Provinsi Kalimantan Utara terdiri atas lima wilayah administrasi dengan empat kabupaten dan satu kota madya, yaitu Kabupaten Bulungan, Kabupaten Malinau, Kabupaten Nunukan, Kabupaten Tana Tidung, dan Kota Tarakan.

Pertumbuhan ekonomi merupakan salah satu indikator makro untuk melihat kinerja perekonomian secara riil di suatu wilayah. Laju pertumbuhan ekonomi dihitung berdasarkan perubahan PDRB atas dasar harga konstan tahun yang bersangkutan terhadap tahun sebelumnya. Pertumbuhan ekonomi dapat dipandang sebagai 
pertmbahan jumlah barang dan jasa yang dihasilkan oleh semua lapangan usaha kegiatan ekonomi yang ada di suatu wilayah selama kurun waktu setahun.

Berdasarkan harga konstan 2010, nilai PDRB Kalimantan Utara pada tahun 2019 meningkat. Peningkatan tersebut dipengaruhi oleh meningkatnya produksi di seluruh lapangan usaha yang sudah bebas dari pengaruh inflasi. Nilai PDRB Kalimantan Utara atas dasar harga konstan 2010 pada tahun 2019, mencapai 61,83 triliun rupiah. Angka tersebut naik dari 57,84 triliun rupiah pada tahun 2018. Hal tersebut menunjukkan bahwa selama tahun 2019 terjadi pertumbuhan ekonomi sebesar 6,91 persen, lebih tinggi jika dibandingkan dengan pertumbuhan ekonomi tahun sebelumnya yang mencapai 6,05 persen. Dari 17 lapangan usaha ekonomi yang ada, seluruhnya mengalami pertumbuhan yang positif. Dua belas lapangan usaha mengalami pertumbuhan positif sebesar lima hingga sembilan persen.

Ada satu lapangan usaha mengalami pertumbuhan lebih dari 10 persen, sedangkan sisanya mengalami pertumbuhan kurang dari 5 persen.

Lapangan usaha pertanian, kehutanan dan perikanan salah satunya yang mengalami pertumbuhan yang positif yaitu sebesar 5,78 persen; pengadaan listrik dan es sebesar 5,47 persen; real estat sebesar 5,46 persen; dan jasa keuangan dan asuransi sebesar 5,39 persen.

Ukuran laju pertumbuhan ekonomi dihitung dengan menggunakan nilai hasil Produk Domestik Regional Bruto (PDRB). Perkembangan PDRB Provinsi Kalimantan Utara atas harga konstan (2010) tahun 2014-2018 persen disajikan pada Tabel 1.

Berdasarkan tabel 1 dapat diketahui bahwa sumbangan terbesar terhadap total PDRB adalah sektor pertambangan dan penggalian. Sektor pertanian, kehutanan dan perikanan menempati urutan ke 15 dengan sumbangan total terhadap PDRB Provinsi Kalimantan Utara adalah rata-rata sebesar 0.17 persen dari periode tahun 2014-2018. Semakin besar kontribusi PDRB sektor pertanian terhadap total PDRB, maka semakin besar pengaruhnya terhadap pertumbuhan ekonomi total, begitupula sebaliknya (Widianingsih et al., 2016). 
Tabel 1.

Laju Perkembangan PDRB Provinsi Kalimantan Utara Atas Harga Konstan Tahun 2010

\begin{tabular}{|c|c|c|c|c|c|}
\hline \multirow[t]{2}{*}{$\begin{array}{l}\text { Komponen PDRB berdasarkan } \\
\text { Lapangan Usaha }\end{array}$} & \multicolumn{5}{|c|}{$\begin{array}{c}\text { Distribusi Komponen PDRB* } \\
(\%) \text { atas dasar harga konstan } \\
2010 \\
\end{array}$} \\
\hline & 2014 & 2015 & 2016 & 2017 & 2018 \\
\hline $\begin{array}{l}\text { A. Pertanian, Kehutanan, dan } \\
\text { Perikanan }\end{array}$ & 0.17 & 0.17 & 0.18 & 0.17 & 0.17 \\
\hline B. Pertambangan dan Penggalian & 32.17 & $\begin{array}{r}30.3 \\
0\end{array}$ & $\begin{array}{r}28.2 \\
3\end{array}$ & $\begin{array}{r}28.3 \\
2\end{array}$ & $\begin{array}{r}27.9 \\
4\end{array}$ \\
\hline C. Industri Pengolahan & 9.35 & 9.60 & 9.85 & 9.73 & 9.34 \\
\hline D. Pengadaan Listrik dan Gas & 0.05 & 0.06 & 0.06 & 0.06 & 0.07 \\
\hline $\begin{array}{l}\text { E. Pengadaan Air, Pengelolaan } \\
\text { Sampah, Limbah dan Daur Ulang }\end{array}$ & 0.07 & 0.07 & 0.07 & 0.07 & 0.07 \\
\hline F. Konstruksi & 11.55 & $\begin{array}{r}11.5 \\
8\end{array}$ & $\begin{array}{r}12.1 \\
2\end{array}$ & $\begin{array}{r}12.0 \\
5\end{array}$ & $\begin{array}{r}12.2 \\
4\end{array}$ \\
\hline $\begin{array}{l}\text { G. Perdagangan Besar dan Eceran; } \\
\text { Reparasi Mobil dan sepeda motor }\end{array}$ & 10.10 & $\begin{array}{r}10.0 \\
5\end{array}$ & $\begin{array}{r}10.3 \\
6\end{array}$ & $\begin{array}{r}10.5 \\
2\end{array}$ & $\begin{array}{r}10.8 \\
0\end{array}$ \\
\hline H. Transportasi dan Pergudangan & 5.65 & 5.92 & 6.05 & 6.28 & 6.44 \\
\hline $\begin{array}{l}\text { I. Penyediaan Akomodasi dan } \\
\text { Makan Minum }\end{array}$ & 1.20 & 1.24 & 1.29 & 1.37 & 1.45 \\
\hline J. Informasi dan Komunikasi & 2.41 & 2.65 & 2.77 & 2.84 & 2.92 \\
\hline K. Jasa Keuangan dan Asuransi & 1.08 & 1.12 & 1.15 & 1.12 & 1.14 \\
\hline L. Real Estate & 0.97 & 0.98 & 0.96 & 0.94 & 0.94 \\
\hline M. Jasa Perusahaan & 0.30 & 0.29 & 0.26 & 0.26 & 0.25 \\
\hline $\begin{array}{l}\text { N. Administrasi Pemerintahan, } \\
\text { Pertahanan dan Jaminan dan } \\
\text { sosial wajib }\end{array}$ & 4.77 & 4.90 & 5.10 & 5.10 & 5.10 \\
\hline O. Jasa Pendidikan & 2.17 & 2.31 & 2.38 & 2.40 & 2.38 \\
\hline $\begin{array}{l}\text { P. Jasa Kesehatan dan Kegiatan } \\
\text { Sosial }\end{array}$ & 0.89 & 1.01 & 1.10 & 1.10 & 1.09 \\
\hline Q. Jasa Lainnya & 0.47 & 0.54 & 0.58 & 0.58 & 0.59 \\
\hline
\end{tabular}

Data : Badan Pusat Statistik, 2019, diolah

Khusus untuk sektor pertanian yang di dalamnya mencakup pertanian, peternakan, perburuan dan jasa di dalamnya terdapat sub sektor tanaman pangan yang mempunyai pertumbuhan seperti ditunjukkan pada tabel 2 berikut. 
Tabel 2.

Laju pertumbuhan dan Peranan terhadap PDRB Subkategori Lapangan Usaha Pertanian, Peternakan, Perbutuan dan jasa

\begin{tabular}{|c|c|c|c|c|c|}
\hline $\begin{array}{c}\text { Subkategori Lapangan Usaha } \\
\text { Pertanian, Peternakan, } \\
\text { Perbutuan dan jasa }\end{array}$ & 2014 & 2015 & 2016 & 2017 & 2018 \\
\hline a. Tanaman Pangan & 13.95 & 10.78 & 12.60 & 11.99 & 7.27 \\
\hline $\begin{array}{l}\text { b. Tanaman Hortikultura } \\
\text { Semusim }\end{array}$ & 11.75 & 9.65 & 11.64 & 11.11 & 11.31 \\
\hline c. Perkebunan Semusim & 0.02 & 0.01 & 0.02 & 0.02 & 0.02 \\
\hline $\begin{array}{l}\text { d. Tanaman Hortikultura } \\
\text { Tahunan dan Lainnya }\end{array}$ & 20.02 & 13.55 & 15.95 & 15.20 & 15.61 \\
\hline e. Perkebunan Tahunan & 40.96 & 35.37 & 46.70 & 48.45 & 51.95 \\
\hline f. Peternakan & 11.41 & 9.24 & 11.28 & 11.43 & 12.01 \\
\hline $\begin{array}{l}\text { g. Jasa Pertanian dan } \\
\text { Perburuan }\end{array}$ & 1.90 & 21.40 & 1.82 & 1.79 & 1.83 \\
\hline
\end{tabular}

Data: Badan Pusat Statistik 2019, diolah

Sub Sektor tanaman pangan merupakan sub sektor unggulan ke tiga setelah sub sektor perkebunan tahunan dan tanaman hortikultura tahunan lainnya.

Tanaman pangan yang di menjadi unggulan di provinsi Kalimantan Utara adalah padi, jagung, kacang tanah, kacang hijau, ubi kayu, ubi jalar, dan kedelai.

Capaian Produksi tanaman pangan terbesar tahun 2019 adalah pada tanaman padi (33.357 ton), jagung (3.273 ton), dan ubi kayu (38.957 ton) (Dinas Pertanian dan Tanaman pangan provinsi Kalimantan Utara 2020).

Berdasarkan tabel 2, dapat dilihat bahwa persentasi nilai PDRB sub sektor tanaman pangan mengalami penurunan dari tahun 2017 sebesar 11.99 persen menurun menjadi 7.27 di tahun 2018. Tidak seperti pada sub sektor perkebunan tahunan yang di tahun 2018 mempunyai nilai yang meningkat yakni 51.95 persen.

\section{Prospek Komoditas Padi Provinsi Kalimantan Utara}

Tanaman pangan yang diusahakan di Provinsi Kalimantan Utara terdiri dari padi, jagung, kacang tanah, kacang hijau, ubi kayu, ubi jalar, dan kedelai. Komoditas padi diharapkan dapat memenuhi kebutuhan pokok masyarakat Kalimantan Utara dan nantinya dapat menunjang kebutuhan pangan ke Ibu Kota baru, dan diharapkan dapat memberikan masukan yang berarti baik dalam peningkatan pendapatan, taraf kesejahteraan patani di Kalimantan Utara. 
Untuk memproyeksikan produksi padi digunakan analisis trend. Pendugaan persamaan proyeksi menggunakan metode kuadrat terkecil (Least Square).

Persamaan garis trend linier produksi padi yang diperoleh berdasar metode kuadrat terkecil adalah :

$$
Y=129615-12648 X
$$

Nilai koefisien trend sebesar 12648 berarti bahwa produksi padi di Provinsi Kalimantan Utara setiap tahunnya mengalami penurunan produksi selama periode proyeksi yaitu sebesar 12.648 ton pada setiap tahun. Hal ini disebabkan intersep pada persamaan garis trend linier adalah sebesar 129.615 yang berarti bahwa jumlah produksi padi pada tahun dasar (2013) sebesar 129.615 ton.

Penurunan produksi padi di Provinsi Kalimantan Utara disebabkan oleh beberapa faktor antara lain luas panen produksi padi turun, dan produktivitas lahan yang cenderung telah mengalami pelandaian (levelling off).

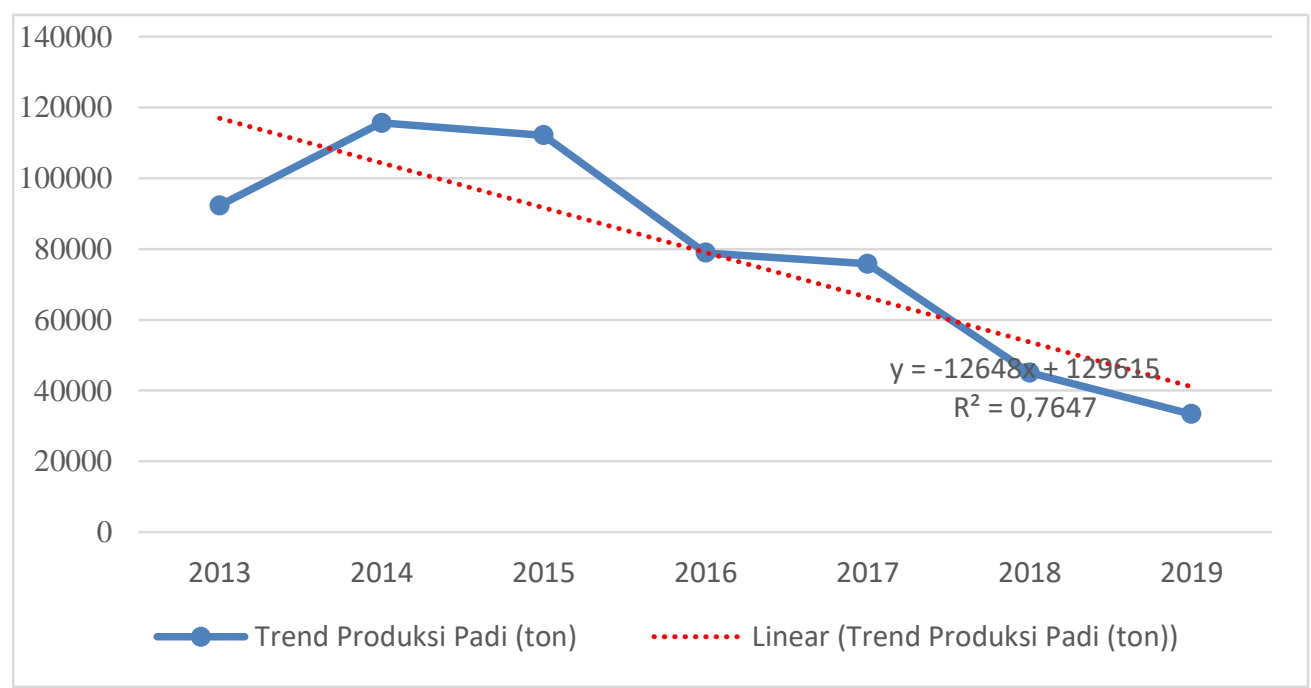

Gambar 1. Trend Produksi Komoditas Padi Tahun 2014-2018

Daerah kabupaten/kota di Provinsi Kalimantan Utara yang memiliki luas panen dan produksi padi (padi sawah dan padi ladang) terbesar adalah Kabupaten Bulungan. Luas panen padi di kabupaten ini mencapai 19.793 ha dengan produktivitas $35,20 \mathrm{ku} / \mathrm{ha}$ sehingga produksi padi yang dicapai sebesar
69.676 ton pada tahun 2013. Dengan kata lain 55,86 persen produksi padi di Kalimantan Utara dihasilkan oleh Kabupaten Bulungan. Bahkan untuk jenis padi sawah produksi dari Bulungan mencapai 58,31 persen dari total padi sawah Kalimantan Utara (BPS, 2013). 


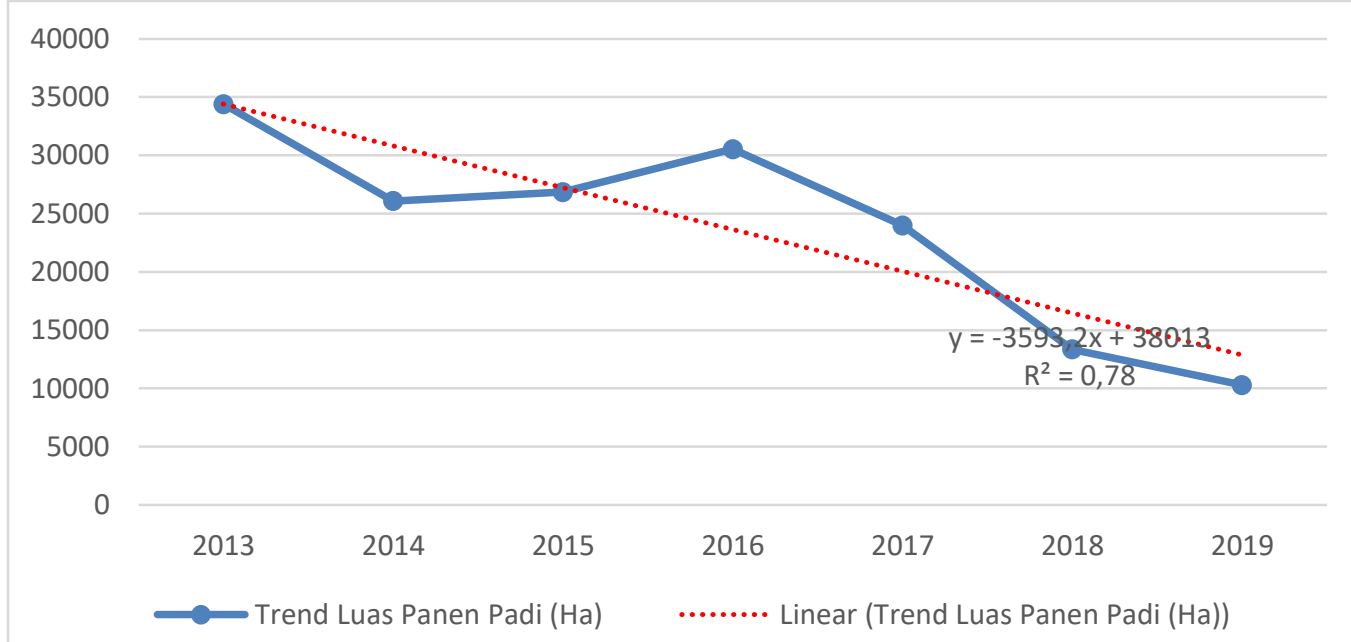

Gambar 2. Trend Luas Panen Padi Periode Tahun 2013-2014

Trend penurunan produksi padi yang disebabkan sebabkan karena trend penurunan luas panen, dapat dilihat pada periode tahun 2016 sampai tahun 2019, grafik produksi padi dengan luas panen padi mempunyai pola yang sama yaitu mengalami kenaikan di tahun 2016 dan terus mengalami penurunan hingga tahun 2019.

Trend penurunan produksi dan luas panen padi di provinsi Kalimantan Utara dapat dilihat pada gambar 1 dan gambar 2.

Hasil penelitian mengenai Hubungan antara luas lahan pertanian dan produksi padi di kalimantan Utara yang dilakukan oleh Harini, Ariani, Supriyati, \& Satriagasa, (2019) menunjukkan bahwa luas lahan pertanian di Kalimanan Utara tahun 2012-2017 mengalami perubahan sebesar 4.955
Ha atau sekitar 19,56 persen. Komoditas padi di Kalimantan Utara secara umum mengalami penurunan sebesar 25.468 ton atau 0,04 persen, sedangkan luas lahan pertanian secara signifikan $(0,029)$ berpengaruh terhadap produksi padi di Kalimantan Utara.

Salah satu faktor pendukung peningkatan produksi padi adalah karena terjadinya peningkatan produktivitas.

Gambar 3 menunjukkan bahwa trend produktivitas padi di Kalimantan Utara selama periode 2013-2019 cenderung mengalamai pelandaian atau yang disebut fenomena levelling off. Lefelling off yaitu suatu kondisi dimana produksi padi meningkat setiap tahunnya, namun laju pertumbuhan produksinya cenderung menurun (Maulana, 2016) 


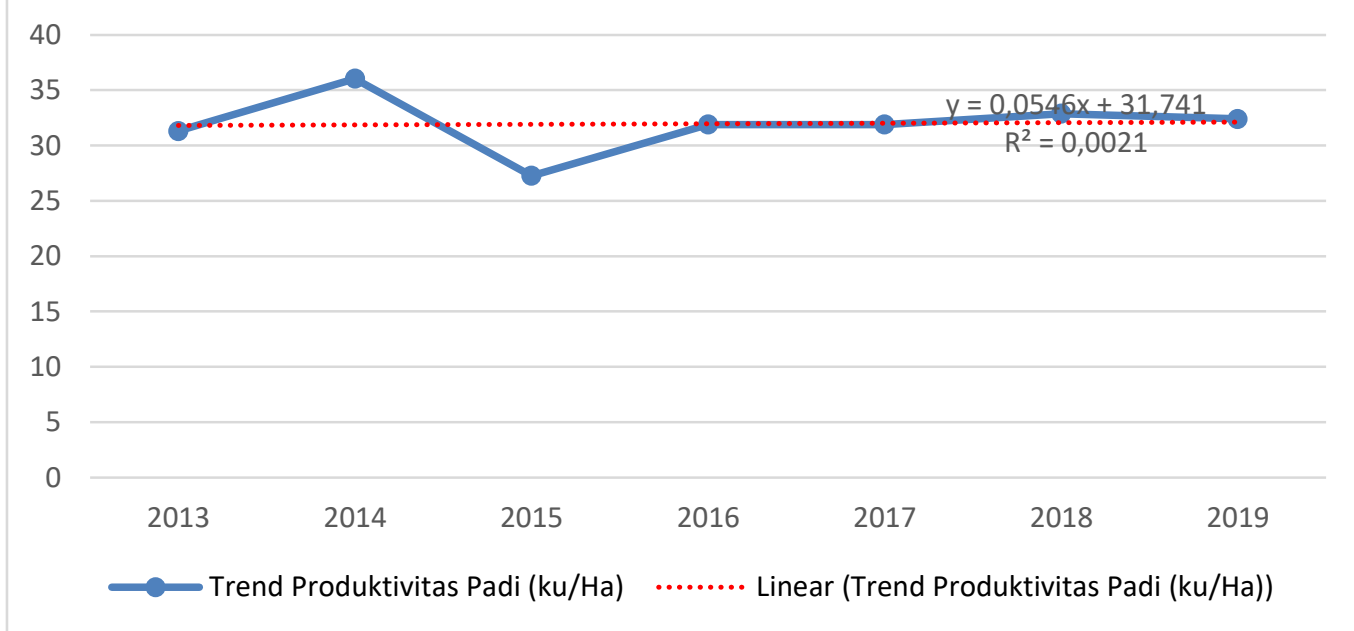

Gambar 3. Trend Produktivitas Padi Periode Tahun 2013-2019

Rata-rata produktivitas padi adalah sebesar $31.96 \mathrm{ku} / \mathrm{Ha}$ baik padi ladang maupun padi sawah. Produktivitas padi di Kalimantan Utara berada di bawah rata-rata produktivitas secara nasional yaitu sebesar $51.14 \mathrm{ku} / \mathrm{Ha}$ (BPS, 2020).

Hal ini mengindikasikan bahwa perlu adanya strategi kebijakan yang harus dilakukan pemerintah untuk merangsang peningkatan produktivitas lahan petani agar dapat mencapai rata-rata produktivitas padi secara nasional. Strategi kebijakan peningkatan produksi yang dilakukan dapat melalui pengembangan riset teknologi pertanian, pengendalian konversi lahan ke nonpertanian dan pengembangan infrastruktur.

Upaya lainnya dapat dilakukan melalui program penyediaan dan pengembangan sarana dan prasaran pertanian yang meliputi pendataan lahan, rehabilitasi jaringan irigasi, konstruksi, pembangunan embung, cetak sawah, perbaikan infrastruktur lahan rawa hingga penyediaan sarana produksi mendukung cetak sawah dan alat dan mesin pertanian pra panen sub sektor tanaman pangan serta meningkatkan SDM petani dan keterampilan mereka dalam bercocok tanam.

\section{Kontribusi Subsektor Tanaman Pangan Terhadap PDRB Sektor Pertanian, Peternakan, Perbutuan dan Jasa di Provisi Kalimantan Utara.}

Tanaman pangan yang diusahakan di Provinsi Kalimantan Utara terdiri dari padi, jagung, kacang tanah, kacang hijau, ubi kayu, ubi jalar, dan kedelai. Nilai kontribusi tanaman pangan diperoleh dengan cara membandingkan antara PDRB tanaman pangan dengan PDRB sektor Pertanian, Peternakan, Perburuan dan Jasa.

Sumbangan sub sektor tanaman pangan terhadap total sektor 
pertanian, peternakan, perburuan dan jasa tinggi jika persentasinya lebih dari 15.09 persen. Kontribusi sub sektor tanaman pangan terhadap total
PDRB sektor pertanian, peternakan, perburuan dan jasa selama tahun 2014 sampai 2018 dalam persentasi dapat diliht dari tabel 3 berikut.

Tabel 3.

Kontribusi Sub Sektor Tanaman Pangan Terhadap Total PDRB Sektor Pertanian, Peternakan, Perburuan dan Jasa

\begin{tabular}{cccc}
\hline Tahun & $\begin{array}{c}\text { PDRB Tanaman } \\
\text { Pangan (juta } \\
\text { rupiah) }\end{array}$ & $\begin{array}{c}\text { PDRB Pertanian, } \\
\text { Peternakan, } \\
\text { Perburuan dan Jasa } \\
\text { (juta rupiah) }\end{array}$ & Kontribusi (\%) \\
\hline 2014 & $385,736.30$ & $2,764,629.50$ & 13.95 \\
2015 & $385,736.30$ & $2,857,029.00$ & 13.50 \\
2016 & $385,736.30$ & $3,015,881.30$ & 12.79 \\
2017 & $385,736.30$ & $3,166,543.80$ & 12.18 \\
2018 & $235,288.90$ & $3,236,762.00$ & 7.27 \\
\hline Rata-rata & $\mathbf{3 5 5 6 4 6 . 8 2}$ & $\mathbf{3 0 0 8 1 6 9 . 1 2}$ & $\mathbf{1 1 . 9 4}$
\end{tabular}

Sumber data : Data sekunder, diolah tahun 2020

Tabel 3 menujukkan nilai persentase kontribusi tanaman pangan terhadap sub sektor pertanian, peternakan, perburuan dan jasa selama tahun 2014-2018. Selama periode tersebut, persentase kontribusinya memiliki nilai rendah(11.94 persen) karena nlai tersebut di atas kontribusi rata-rata total sektor pertanian, peternakan, perburuan dan jasa (7 sub sektor) yaitu 15.09 persen. Sub sektor perkebunan tahunan yang memiliki kontribusi tinggi yaitu sebesar 46,76 persen.

Kontribusi subsektor tanaman pangan terhadap sektor pertanian, peternakan, perburuan dan jasa selama tahaun 2014-2018 bernilai rata-rata 11.94 persen artinya setiap 1 juta rupiah nilai dari total tanaman pertanian peternakan perburuan dan jasa, maka komoditas tanaman pangan yaitu sebesar Rp 119.40 sisanya dari sub sektor lainnya (6 sub sektor).

Tahun $2018 \quad$ kontribusi subsektor pertanian mengalami penurunan sebesar 4.91 persen dari tahun sebelumnya. Hal ini diakibatkan salah satunya karena tren penurunan produksi padi. Perkembangan kontribusi komoditas tanaman pangan terhadap sub sektor pertanian, peternakan, perburuan, dan jasa lainnya dapat di lihat pada gambar 4 berikut. 


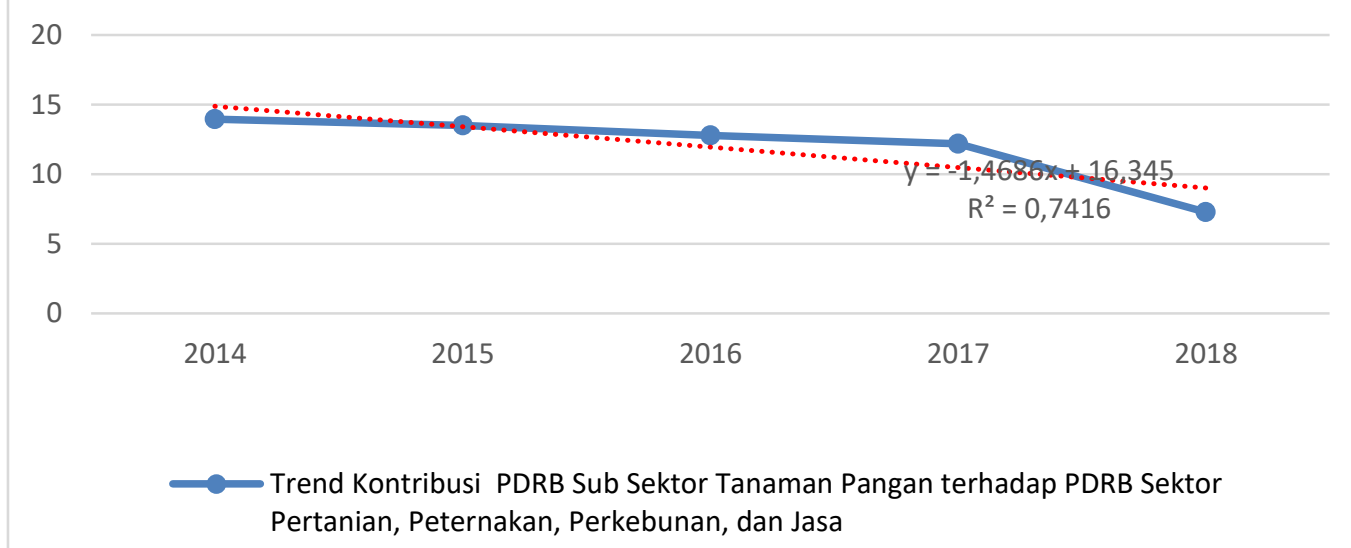

Gambar 4. Trend Kontribusi PDRB Sub Sektor Tanaman Pangan terhadap PDRB Sektor Pertanian, Peternakan, Perkebunan, dan Jasa Periode Tahun 2013-2014

Rendahnya kontribusi pangan terhadap PDRB sektor pertanian membuktikan bahwa sektor pangan khususnya padi belum dapat dijadikan sebagai komoditas yang dapat diunggulkan dan dapat mendukung terhadap penyususnan pendapatan Provinsi Kalimantan Utara. Dan juga belum siap dijadikan sebagai daerah penyangga pangan untuk ibu kota negara nantinya.

Untuk itu, tanaman pangan perlu diupayakan untuk terus ditingkatakan produksinya minimal dapat memenuhi kebutuhan masyarakat provinsi Kalimantan utara terlebih dahulu, sehingga tidak terlalu bergantung dengan beras dari luar sepertia Malaysia dan Sulawesi.

\section{SIMPULAN}

1. Perkembangan komoditas padi di Provisi Kalimantan Utara mempunyai prospek yang kurang bagus ditinjau dari produksi, luas panen dan produktivitasnya. Produksi padi cenderung mengalami penurunan yang diakibatkan olah penurunan luas panen, sedangkan produktivitasnya cenderung mengalami pelandaian (levelling off). Hal ini menunjukkan bahwa komoditas padi belum mampu dijadikan sebagai sektor unggulan di provinsi Kalimantan Utara.

2. Kontribusi subsektor tanaman Pangan Terhadap PDRB Sektor Pertanian, Peternakan, Perbutuan dan Jasa di Provisi Kalimantan Utara sebesar 11.94 persen di bawah rata-rata kontribusi di sektor tersebut (15.09 persen) sehingga dapat disimpulkan bahwa Provinsi Kalimantan Utara belum bisa mengandalkan sub sektor tanaman pangan untuk peningkatan PDRB. 


\section{DAFTAR PUSTAKA}

Anonim. 2020. Benahi Pertanian 3 Kabupaten penyangga pangan IKN Baru. Media Kaltara.com.

Https://mediakaltara.com/ben ahi-pertanian-3-kabupatenpenyangga-pangan-iknbaru.Diakses pada tanggal 28 Oktober 2020.

Ariani, M. (2004). Penguatan Ketahanan Pangan Daerah untuk Mendukung Ketahanan Pangan Nasional. Pusat Analisis Sosial Ekonomi Dan Kebijakan Pertanian.

Badan Pengawas Keuangan dan Pembangunan. 2018. BPKP Evaluasi Tata Kelola Beras di Wilayah Kaltara. Media Online BPKP. Retrieved from http://www.bpkp.go.id.

BPS. (2014). Provinsi Kalimantan Utara dalam Angka 2014. In BPS Provinsi Kalimantan Utara.

BPS. (2015). Provinsi Kalimantan Utara dalam Angka 2015. In BPS Provinsi Kalimantan Utara.

BPS. (2016). Provinsi Kalimantan Utara dalam Angka 2016. In BPS Provinsi Kalimantan Utara.

BPS. (2017). Provinsi Kalimantan Utara dalam Angka 2017. In BPS Provinsi Kalimantan Utara.

BPS. (2018). Provinsi Kalimantan
Utara dalam Angka 2018. In BPS Provinsi Kalimantan Utara.

BPS (2019). Provinsi Kalimantan Utara dalam Angka 2019. In BPS Provinsi Kalimantan Utara.

BPS. (2020). Provinsi Kalimantan Utara dalam Angka 2020. In BPS Provinsi Kalimantan Utara.

https://kaltara.bps.go.id/publi cation/

BPS. (2020). Luas Panen Dan Produksi Padi Di Indonesia 2019. Berita Resmi Statistik.

Harini, R., Ariani, R. D., Supriyati, S., \& Satriagasa, M. C. (2019). Analisis Luas Lahan Pertanian Terhadap Produksi Padi Di Kalimantan Utara. Jurnal Kawistara. Https://Doi.Org/10.22146/Ka wistara.38755

Maulana, M. (2016). Peranan Luas Lahan, Intensitas Pertanaman Dan Produktivitas Sebagai Sumber Pertumbuhan Padi Sawah Di Indonesia 19802001. Jurnal Agro Ekonomi. Https://Doi.Org/10.21082/Jae .V22n1.2004.74-95

Tirani, T., Pranoto, Y. S., \& Moelyo, H. (2018). Kontribusi Sektor Pertanian Berdasarkan Keunggulan Wilayah Di Kabupaten Bangka. Caraka Tani: Journal Of Sustainable Agriculture.

Https://Doi.Org/10.20961/Car 
akatani.V33i1.19662.

Widianingsih, W., Suryantini, A., \&

Irham, I. (2016). Kontribusi

Sektor Pertanian Pada

Pertumbuhan Ekonomi Di

Provinsi Jawa Barat. Agro

Ekonomi.

https://doi.org/10.22146/agro

ekonomi.17272 